\title{
Experience of Using Transpedicular Osteosynthesis in Traumatic Spondylolisthesis of the Axis
}

\author{
DOI: $10.17691 / \mathrm{stm} 2021.13 .5 .06$
}

Received March 22, 2021

I.V. Basankin, MD, DSc, Head of Neurosurgical Unit No. $3^{1}$;

A.A. Giulzatyan, MD, PhD, Neurosurgeon';

P.B. Nesterenko, Orthopedist ${ }^{1}$;

A.B. Bagaudinov, Neurosurgeon ${ }^{1}$;

D.A. Tayurski, Student, Medical Faculty2;

M.L. Mukhanov, MD, PhD, Assistant, Department of Orthopedics, Traumatology and Military Field Surgery2

${ }^{1}$ Scientific Research Institute - Ochapovsky Regional Clinical Hospital No.1, Ministry of Health

of Krasnodar Region, 167, $1^{\text {st }}$ Maya St., Krasnodar, 350086, Russia;

${ }^{2}$ Kuban State Medical University, 4 M. Sedina St., Krasnodar, 350063, Russia

The aim of the study was to assess the efficacy and safety of direct posterior transpedicular osteosynthesis in traumatic spondylolisthesis of $\mathrm{C}_{2}$ vertebra.

Materials and Methods. The present study is an observational retrospective analysis of the results of surgical treatment of 19 patients operated on in 2014-2020 using the posterior transpedicular osteosynthesis technique with Herbert's compression screws for a Hangman's fracture type II according to Levine-Edwards classification. After the operation, the follow-up period lasted for 22 [10; 36] months.

Results. The study group of patients $(n=19)$ made $2.48 \%$ of all patients operated on for traumatic injury of the cervical spine $(n=766)$ in the period from 2014 to 2020. In all cases, the surgical treatment was successful; there were no intraoperative complications in the form of damage to the vascular and nerve structures. The average duration of surgery was $70.8 \pm 24.5 \mathrm{~min}$, and intraoperative blood loss was $92.9 \pm 41.8 \mathrm{ml}$. The length of hospitalization stay was $7[5 ; 17]$ days. On the postoperative CT scans, no significant screw malposition (>2 mm) was found.

Conclusion. Transpedicular osteosynthesis with compression screws in $\mathrm{C}_{2}$ traumatic spondylolisthesis is a safe and sparing operation with a short duration and insignificant blood loss. Thorough preoperative planning and knowledge of the anatomic landmarks make it possible to perform this operation effectively under the C-arm X-ray system control without any navigation system.

Key words: spinal cord injury; upper cervical spine injury; Hangman's fracture; transpedicular fixation; $\mathrm{C}_{2}$ fracture; Judet operation.

How to cite: Basankin I.V., Giulzatyan A.A., Nesterenko P.B., Bagaudinov A.B., Tayurski D.A., Mukhanov M.L. Experience of using transpedicular osteosynthesis in traumatic spondylolisthesis of the axis. Sovremennye tehnologii v medicine 2021; 13(5): 47, https://doi. org/10.17691/stm2021.13.5.06

This is an open access article under the CC BY 4.0 license (https://creativecommons.org/licenses/by/4.0/).

\section{Introduction}

Fractures of the second cervical vertebra $\mathrm{C}_{2}$ (axis) often occur both in elderly and young age [1]. According to the data of the Sweden National Patient Register [2], the incidence of $\mathrm{C}_{2}$ fractures has doubled (from 3 to 6 per 100,000 population) from 1997 to 2014 . According to literary sources [3-6], the incidence of such fractures makes $9-18 \%$ of all types of traumatic injuries of the cervical spine, the odontoid process (dens) fracture accounting for $35-78 \%$, while $C_{2}$ traumatic spondylolisthesis - for $11-25 \%$.

Traumatic spondylolisthesis of the $\mathrm{C}_{2}$ vertebra, or the so-called Hangman's fracture, was described for the first time by Schneider et al. in 1965 [7]. This type of injury occurs as a result of falls, diving, or road accident due to hyperextension and axial load acting on the axis [8].

This injury is treated with conservative and surgical methods aiming at achieving external or using a Philadelphia collar for 10-14 weeks [9]. This technique is used only in neurologically intact and stable LevineEdwards type I fractures, and in this case, good clinical and functional results with a high rate of fracture consolidation (up to 100\%) have been noted [8].

Treating $\mathrm{C}_{2}$ traumatic spondylolisthesis by halo traction and reposition using Gardner-Wells brackets is a well-known technique employed by many specialists. Vaccaro et al. [10] consider traction, reposition, and early rigid immobilization to be an effective method of treatment of type II and Ila axis traumatic spondylolisthesis in the majority of cases. At angulation $>12^{\circ}$, a long immobilization period is required to achieve adequate consolidation [10]. However, this technique limits essentially the functionality of the extremely biomechanically important upper cervical spine. Tolerance to halo immobilization is especially reduced in

Corresponding author: Abram A. Giulzatyan, e-mail: abramgulz@gmail.com 
elderly and aged people. In this regard, great attention in choosing a treatment technique is paid not only to reliable spondylosynthesis but to the functionality of the damaged segment as well.

Surgical management of the Hangman's fracture includes several anterior and posterior stabilizing techniques. Depending on the fracture type, anterior cervical spondylodesis of $\mathrm{C}_{2}-\mathrm{C}_{3}$, transpedicular osteosynthesis of $\mathrm{C}_{2}$, direct spondylosynthesis of $\mathrm{C}_{2}-\mathrm{C}_{3}$ or $C_{1}-C_{2}-C_{3}$ are performed [11-14]. All surgical methods except direct spondylosynthesis of the $\mathrm{C}_{2}$ vertebra block the spine motion segment and significantly restrict the range of motion in the upper cervical spine.

Direct transpedicular osteosynthesis of $\mathrm{C}_{2}$ in Hangman's fracture was first mentioned in the work of Leconte [15] and further popularized by Judet [16]. This method was recognized to be a physiological operation as fixed is only the fracture, not the motion segment.

The aim of the study was to assess the efficacy and safety of the direct transpedicular osteosynthesis in traumatic spondylolisthesis of the $\mathrm{C}_{2}$ vertebra.

\section{Materials and Methods}

The present study is an observational retrospective analysis of a series of cases $(<50)$. Patients with isolated or combined traumatic spondylolisthesis of the $\mathrm{C}_{2}$ vertebra were the object of the investigation. The subject of the study was the technique of direct transpedicular osteosynthesis of the $\mathrm{C}_{2}$ vertebra with Herbert's compression screws, its efficacy, and its influence on patients' quality of life.

The results of surgical treatment of 19 patients operated on for Hangman's fracture in the period from 2014-2020 using direct transpedicular osteosynthesis have been retrospectively analyzed. The study was performed following the requirements of Declaration of Helsinki (2013) and approved by the Ethical Committee of Scientific Research Institute - Ochapovsky Regional Clinical Hospital No.1 (Krasnodar, Russia). Written informed consent for participation in the study was obtained from each patient.

Inclusion criteria were as follows:

patient age 18-70 years;

Levine-Edwards type II Hangman's fracture.

Exclusion criteria implied:

abnormal development of $\mathrm{C}_{2}$ pedicles;

multifragmental fracture of the axis pedicles;

severe somatic comorbidity.

The distribution of the changes found in the spine was performed according to Levine-Edwards classification (to define the fracture type) [17] which was developed on the basis of classification proposed by Effendi [18] and is now most popular. It distinguishes four types of traumatic spondylolisthesis of the $\mathrm{C}_{2}$ vertebra:

type I - stable fracture, $\mathrm{C}_{2}$ body listhesis $<3 \mathrm{~mm}$, no angulation, $\mathrm{C}_{2}-\mathrm{C}_{3}$ disc is intact;

type II - unstable injury, $\mathrm{C}_{2}$ traumatic antelisthesis
$>3 \mathrm{~mm}$, angulation $>11^{\circ}$, disruption of the posterior longitudinal ligament, vertical fracture line;

type Ila - unstable injury, no traumatic antelisthesis, fracture line is horizontal, not vertical, marked angulation $>11^{\circ}$ without antelisthesis;

type III - unstable injury, type I accompanied by bilateral facet joint dislocation.

To assess the patient's condition objectively, neurological and clinical examination has been conducted; the degree of the spine injury was established using AIS (ASIA Impairment Scale), the intensity of the pain syndrome and quality of life was evaluated according to the visual analogue scale (VAS), and daily life activity restrictions due to neck-related pain were evaluated by the Neck Disability Index (NDI). Life activity restrictions were assessed in percentage terms as all patients omitted 1 or 2 items of the questionnaire (driving, reading). While interpreting the results, the following criteria were taken into consideration: $0-9 \%-$ no daily life restrictions; $10-29 \%$ - slight restriction; 30-49\% moderate; $50-69 \%$ - strong; $>70 \%$ - full restriction. CT was used to visualize the pathologic substrate.

Direct transpedicular osteosynthesis of the $\mathrm{C}_{2}$ vertebra with Herbert's compression screws was performed under C-arm X-ray system control without intraoperative navigation. The axial, frontal, and sagittal CT scans of the upper cervical spine were carefully analyzed in the preoperative period. To define a safe zone for screw insertion, the $\mathrm{C}_{2}$ diameter and height of the pedicles, their mediolateral and rostrocaudal angles, as well as variations of the spine artery course and the spinal canal diameter were taken into account.

Operative intervention was conducted in prone position of the patient with a soft roller under the chest, the head was fixed in the Mayfield clamp. A median incision was made in the projection of the $\mathrm{C}_{0}-\mathrm{C}_{3}$ bodies using the massive spinous process of the $\mathrm{C}_{2}$ vertebra as a landmark. The nuchal ligament was exposed along with the spinous processes. Areas necessary for the insertion of the transpedicular screw were exposed subperiosteally, the inner edges of the $C_{2}$ pedicles were also freed from the periosteum. The cranial edge of the axis arch served as a landmark for screw insertion and the superomedial pedicle border was accessible for visual control (the screw entrance angle was $15-20^{\circ}$, angulation $-10-15^{\circ}$ ). After the installation of the active drainages, the cervical muscles were sutured to the spinous process of the $\mathrm{C}_{2}$ vertebra. Sutures were put in the subcutaneous tissue and the skin.

The follow-up period after the operation was 22 months [10; 36].

Statistical processing of the results. The clinical results obtained were processed using the software package IBM SPSS 16.0. Numeric data are presented as median (Me) and interquartile interval [25; 75] or arithmetic mean \pm standard deviation (M $\pm S T D$ ).

Since the number of patients in the general population was less than 50 , the distribution of numeric values in 
relation to a sample differed essentially from the normal law of distribution (the hypothesis of normal distribution of variables in the population was checked using the Shapiro-Wilk test for normality; $W=0.637$; $p<0.0001$ ), nonparametric methods of statistical analysis and Wilcoxon signed-rank test were applied, and the level of statistical significance $p<0.05$ was accepted as a lower border of confidence.

\section{Results}

The studied cohort of patients $(n=19,14$ males and 5 females) makes $2.48 \%$ of the total number of the operated patients in the period from 2014 to 2020 for traumatic injury of the cervical spine $(n=766)$. All patients were hospitalized to the neurological unit. Patients' age was $22-67$ years. The traumas were caused by a traffic accident in 12 patients (63.2\%) and fall from height in 7 patients $(36.8 \%)$.

The main pre- and postoperative characteristics of the studied patients are presented in Table 1.
There were patients with combined pathology: 5 had brain injury of mild and moderate severity, 6 - fractured ribs and/or traumatic lung injury, 9 - fractures of the limbs, 1 had fracture of the $\mathrm{Th}_{11}$ vertebra.

Neurological symptoms have not been observed in 11 patients $(57.9 \%)$ before and after the operative intervention. Complete regression of neurological symptoms by the AIS scale was noted in 5 people (in 4 from $D$ to $E$, in 1 from $C$ to $E$ ), in 1 patient there was incomplete regression of symptoms according to AIS (from $C$ to D), no significant positive dynamics within the follow-up period was established in 2 patients (D by AIS).

Surgical treatment was successful in all cases, intraoperative complications in the form of damage to the vascular and nerve structures have not been noted. Average duration of the operative intervention was $70.8 \pm 24.5 \mathrm{~min}$, intraoperative blood loss was, on average, $92.9 \pm 41.8 \mathrm{ml}$. Hospital stay lasted for 5-17 days. The postoperative CT examinations did not reveal any significant $(>2 \mathrm{~mm})$ malposition of the screws (Figure 1).

Table 1

\section{Characteristics of patients}

\begin{tabular}{|c|c|c|c|c|c|c|c|c|c|c|}
\hline \multirow{2}{*}{ No. } & \multirow{2}{*}{$\begin{array}{l}\text { Genderl } \\
\text { age }\end{array}$} & \multirow{2}{*}{$\begin{array}{c}\text { Trauma } \\
\text { mechanism }\end{array}$} & \multirow{2}{*}{$\begin{array}{c}\text { Traumatic injury } \\
\text { of other organs and systems }\end{array}$} & \multicolumn{2}{|c|}{$\begin{array}{l}\text { Neurological status } \\
\text { according to AIS }\end{array}$} & \multicolumn{3}{|c|}{$\begin{array}{l}\text { Pains in cervical spine } \\
\text { according to VAS }\end{array}$} & \multicolumn{2}{|c|}{ NDI } \\
\hline & & & & $\begin{array}{l}\text { Before the } \\
\text { operation }\end{array}$ & $\begin{array}{l}\text { After the } \\
\text { operation }\end{array}$ & $\begin{array}{l}\text { Before the } \\
\text { operation }\end{array}$ & $\begin{array}{l}3 \text { days } \\
\text { after the } \\
\text { operation }\end{array}$ & $\begin{array}{l}3 \text { months } \\
\text { after the } \\
\text { operation }\end{array}$ & $\begin{array}{l}\text { Before the } \\
\text { operation }\end{array}$ & $\begin{array}{l}3 \text { months } \\
\text { after the } \\
\text { operation }\end{array}$ \\
\hline 1 & $\mathrm{M} / 23$ & $\begin{array}{l}\text { Traffic } \\
\text { accident }\end{array}$ & $\begin{array}{l}\text { Mild brain injury, fracture } \\
\text { of right radius }\end{array}$ & $D$ & $D$ & 6 & 2 & 1 & 42 & 22 \\
\hline 2 & $\mathrm{M} / 56$ & $\begin{array}{l}\text { Traffic } \\
\text { accident }\end{array}$ & $\begin{array}{l}\text { Fractured ribs, lung contusion, } \\
\text { hemothorax, fracture } \\
\text { of left tibia diaphysis }\end{array}$ & $E$ & $E$ & 6 & 1 & 1 & 35 & 4 \\
\hline 3 & $M / 62$ & Fall & - & $E$ & $E$ & 7 & 2 & 1 & 48 & 7 \\
\hline 4 & $\mathrm{~F} / 22$ & $\begin{array}{l}\text { Traffic } \\
\text { accident }\end{array}$ & $\begin{array}{l}\text { Brain injury of moderate } \\
\text { severity }\end{array}$ & C & $D$ & 5 & 1 & 1 & 53 & 24 \\
\hline 5 & $\mathrm{~F} / 67$ & $\begin{array}{l}\text { Traffic } \\
\text { accident }\end{array}$ & - & $D$ & $E$ & 7 & 2 & 0 & 54 & 2 \\
\hline 6 & $\mathrm{~F} / 34$ & $\begin{array}{l}\text { Traffic } \\
\text { accident }\end{array}$ & $\begin{array}{l}\text { Fractured ribs, lung contusion, } \\
\text { fracture of right humerus } \\
\text { diaphysis }\end{array}$ & $D$ & $E$ & 5 & 1 & 0 & 20 & 2 \\
\hline 7 & $\mathrm{M} / 54$ & $\begin{array}{l}\text { Traffic } \\
\text { accident }\end{array}$ & $\begin{array}{l}\text { Diacondylar fracture } \\
\text { of right humerus }\end{array}$ & $E$ & $E$ & 4 & 1 & 1 & 7 & 0 \\
\hline 8 & $\mathrm{M} / 42$ & $\begin{array}{l}\text { Traffic } \\
\text { accident }\end{array}$ & $\begin{array}{l}\text { Fractured ribs, pneumothorax, } \\
\text { fracture of left fibula }\end{array}$ & $E$ & $E$ & 8 & 3 & 1 & 65 & 6 \\
\hline 9 & $\mathrm{~F} / 48$ & Fall & Mild brain injury & $E$ & $E$ & 6 & 2 & 1 & 39 & 4 \\
\hline 10 & $\mathrm{M} / 44$ & Fall & $\begin{array}{l}\text { Bilateral fracture of radii } \\
\text { with displacement }\end{array}$ & $E$ & $E$ & 6 & 2 & 1 & 35 & 0 \\
\hline 11 & $\mathrm{M} / 51$ & $\begin{array}{l}\text { Traffic } \\
\text { accident }\end{array}$ & $\begin{array}{l}\text { Isolated fracture of left lateral } \\
\text { femoral condyle }\end{array}$ & $E$ & $E$ & 7 & 3 & 1 & 53 & 6 \\
\hline 12 & $\mathrm{M} / 28$ & $\begin{array}{l}\text { Traffic } \\
\text { accident }\end{array}$ & - & D & $E$ & 8 & 1 & 1 & 72 & 4 \\
\hline 13 & $\mathrm{M} / 30$ & $\begin{array}{l}\text { Traffic } \\
\text { accident }\end{array}$ & Fractured ribs, hemothorax & $D$ & $D$ & 8 & 0 & 3 & 62 & 15 \\
\hline
\end{tabular}


End of the Table 1

\begin{tabular}{|c|c|c|c|c|c|c|c|c|c|c|}
\hline \multirow{2}{*}{ No. } & \multirow{2}{*}{$\begin{array}{l}\text { Genderl } \\
\text { age }\end{array}$} & \multirow{2}{*}{$\begin{array}{c}\text { Trauma } \\
\text { mechanism }\end{array}$} & \multirow{2}{*}{$\begin{array}{c}\text { Traumatic injury } \\
\text { of other organs and systems }\end{array}$} & \multicolumn{2}{|c|}{$\begin{array}{l}\text { Neurological status } \\
\text { according to AIS }\end{array}$} & \multicolumn{3}{|c|}{$\begin{array}{l}\text { Pains in cervical spine } \\
\text { according to VAS }\end{array}$} & \multicolumn{2}{|c|}{$\mathrm{NDI}$} \\
\hline & & & & $\begin{array}{l}\text { Before the } \\
\text { operation }\end{array}$ & $\begin{array}{l}\text { After the } \\
\text { operation }\end{array}$ & $\begin{array}{l}\text { Before the } \\
\text { operation }\end{array}$ & $\begin{array}{l}3 \text { days } \\
\text { after the } \\
\text { operation }\end{array}$ & $\begin{array}{l}3 \text { months } \\
\text { after the } \\
\text { operation }\end{array}$ & $\begin{array}{l}\text { Before the } \\
\text { operation }\end{array}$ & $\begin{array}{l}3 \text { months } \\
\text { after the } \\
\text { operation }\end{array}$ \\
\hline 14 & $\mathrm{~F} / 45$ & Fall & Mild brain injury & D & $E$ & 8 & 0 & 0 & 55 & 7 \\
\hline 15 & $M / 65$ & $\begin{array}{l}\text { Traffic } \\
\text { accident }\end{array}$ & $\begin{array}{l}\text { Fracture of left humerus } \\
\text { and left femoral diaphysis }\end{array}$ & $E$ & $E$ & 5 & 3 & 1 & 30 & 2 \\
\hline 16 & $M / 67$ & $\begin{array}{l}\text { Traffic } \\
\text { accident }\end{array}$ & - & $E$ & $E$ & 7 & 2 & 0 & 55 & 0 \\
\hline 17 & $\mathrm{M} / 45$ & Fall & $\begin{array}{l}\text { Brain injury of moderate } \\
\text { severity, compression fracture } \\
\text { of } T h_{11} \text {-vertebra type A1 } \\
\text { according to AOSpine }\end{array}$ & C & $E$ & 6 & 2 & 1 & 47 & 4 \\
\hline 18 & $\mathrm{M} / 57$ & $\begin{array}{l}\text { Traffic } \\
\text { accident }\end{array}$ & $\begin{array}{l}\text { Fractured ribs, fracture } \\
\text { of humeral surgical neck, } \\
\text { right and left }\end{array}$ & $E$ & $E$ & 5 & 3 & 1 & 25 & 6 \\
\hline 19 & $M / 22$ & $\begin{array}{l}\text { Traffic } \\
\text { accident }\end{array}$ & Fractured ribs & $E$ & $E$ & 5 & 1 & 1 & 30 & 0 \\
\hline
\end{tabular}
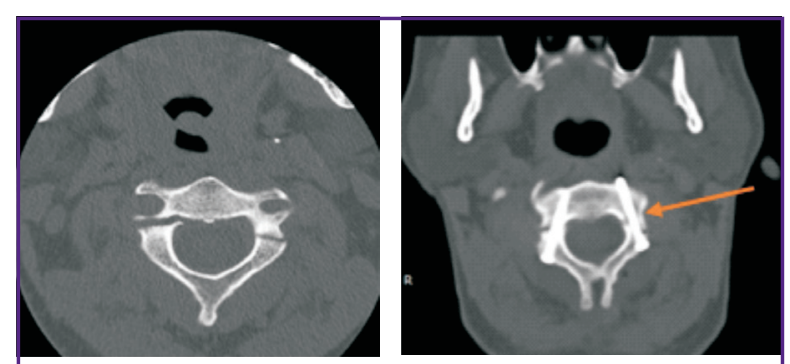

Figure 1. CT scans of the patient with traumatic spondylolisthesis of the $\mathrm{C}_{2}$ vertebra before (a) and after the operation (b)

Arrows show compression screws

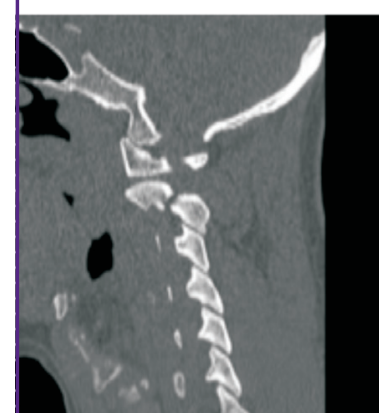

a

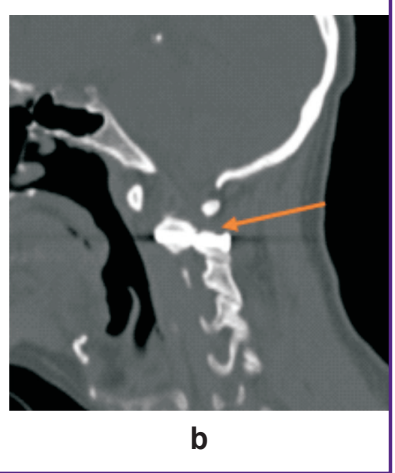

Table 2

VAS and NDI indices before and after surgical treatment

\begin{tabular}{lcccc}
\hline \multirow{2}{*}{ Time of examination } & \multicolumn{2}{c}{ VAS (points) } & \multicolumn{2}{c}{ NDI (\%) } \\
\cline { 2 - 5 } & Me $[25 ; 75]$ & Wilcoxon test; $p$ & Me $[25 ; 75]$ & Wilcoxon test; $p$ \\
\hline Before operation & $6[5 ; 7]$ & $Z_{1}=-3.865$ & $47.0[32.5 ; 54.5]$ & \\
After operation: & & $p<0.001$ & & - \\
$3-4$ days & $2[1 ; 3]$ & $Z_{2}=-3.853$ & - & $Z_{2}=-3.824$ \\
3 months & $1[1 ; 1]$ & $p<0.001$ & $4.0[2.0 ; 6.6]$ & $p<0.001$ \\
\hline
\end{tabular}

$\mathrm{H}$ e r e: $Z_{1}-$ comparing data before the operation and $3-4$ days after it; $Z_{2}-$ comparing data before the operation and 3 months after it. 
Figure 2. CT scans of the 22-yearold female patient with traumatic spondylolisthesis of the $\mathrm{C}_{2}$ vertebra:

(a) preoperative sagittal and axial scans, fracture is visualized, diastasis between fragments on the right $>3.5 \mathrm{~mm}$; (b) 1 day after the operation, transpedicular screws are visualized, no marked malposition (>2 mm) is observed; (c) 6 months after the operation, fracture consolidation is noted
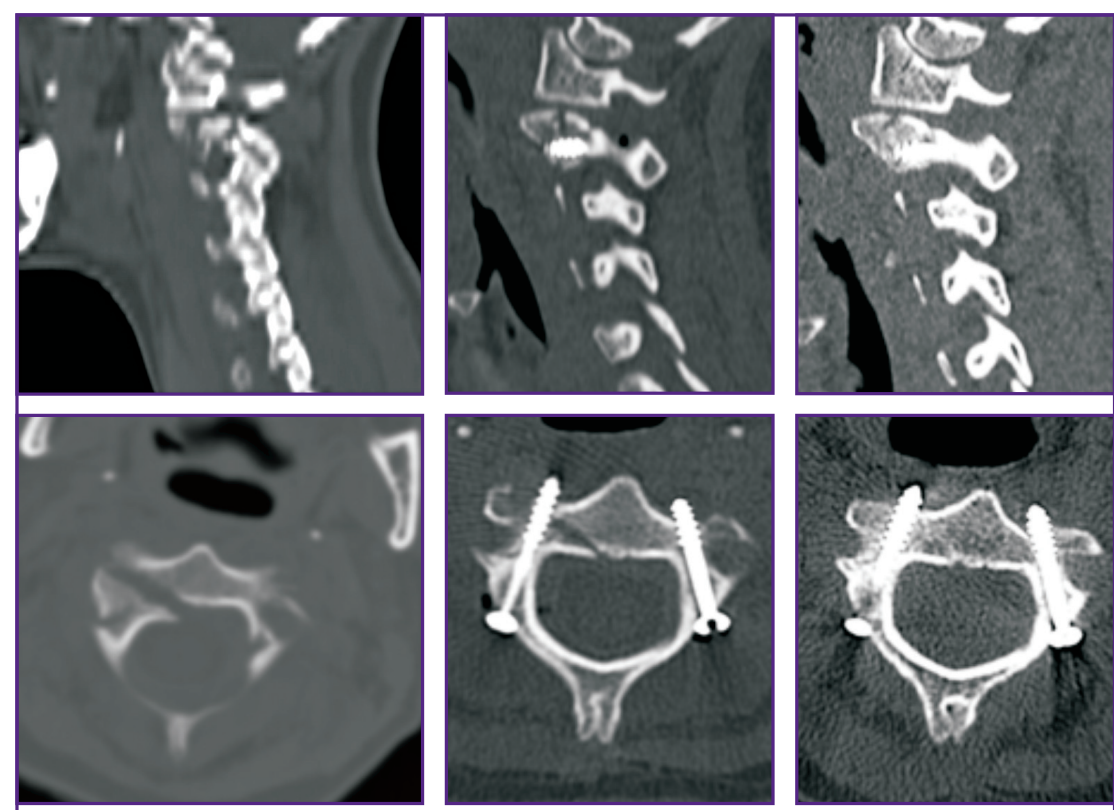

a

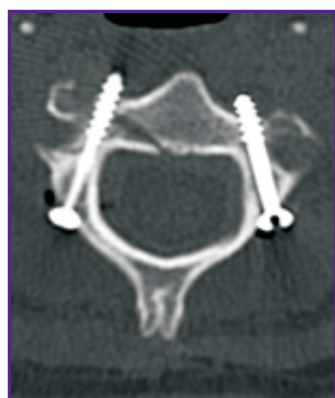

b

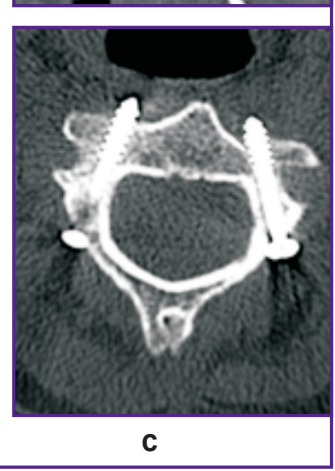

Average postoperative values according to VAS (3-4 days and 3 months after the operation) and NDI (3 months after the operation) were statistically significantly better than the preoperative indices (Table 2).

Further scheduled examinations did not show any negative dynamics in the patients' state and functional restrictions, maximal follow-up period covered 36 months. The signs of complete fracture consolidation in the fixation area were noted no later than 24 months (Figure 2).

\section{Discussion}

Despite the fact that traumatic spondylolisthesis of the $C_{2}$ vertebra was first described in 1965, the choice of the optimal treatment tactics for this injury has remained debatable until now. According to the literary sources $[19,20]$, presently, surgical treatment is recommended in type II, Ila, III Levine-Edwards fractures. Adequate $\mathrm{C}_{2}$ spondylodesis restores the natural axis of the spine by anatomic listhesis reduction and thereby gives patients the possibility to lead an active life.

Several operative techniques of managing $\mathrm{C}_{2}$ traumatic listhesis are described in the literature [21], and $\mathrm{C}_{2}-\mathrm{C}_{3}$ anterior cervical spondylodesis with the use of interbody implants and titanic plates has been historically considered to be traditional. However, it should be noted that this operation is rather difficult to perform technically because of a high risk of damage to the sublingual, facial, and superior laryngeal nerves and vascular structures as well. There is also a high risk of consolidation absence and pseudoarthrosis appearance after the operation since the intervention does not make it possible to operate on the injured $\mathrm{C}_{2}$ structures directly [22]. Due to the above reasons, this operation is not performed routinely for unstable Hangman's fracture treatment.

It should be noted that both anterior cervical spondylodesis and spondylosynthesis of $\mathrm{C}_{2}-\mathrm{C}_{3}$ and $\mathrm{C}_{1}-\mathrm{C}_{2}-\mathrm{C}_{3}$ restrict the mobility of the vertebral motor segment. In direct transpedicular osteosynthesis of the $\mathrm{C}_{2}$ vertebra, the amplitude of axis movements is preserved therefore this operation has been recognized physiological by many authors $[8,23]$. Borne et al. [24] describe 18 patients with Hangman's fracture. Of them, 13 underwent transpedicular osteosynthesis with compression screws. The authors have noted that this method is technically simple, effective, and safe giving good anatomic and functional results. Verheggen and Jansen [25] also report good results of surgical treatment of 13 patients with LevineEdwards types II and Ila fractures who underwent transpedicular fixation. Boullosa with colleagues [26] have demonstrated the results of treating 10 patients with Hangman's fracture types I and II according to Effendi classification; 9 patients were noted to have a good clinical result: fracture consolidation and complete regression of preoperative symptoms. ElMiligui et al. [23] performed surgical treatment using Judet approach to 15 patients with Levine-Edwards type II traumatic spondylolisthesis of the $C_{2}$ vertebra and recognized the technique to be safe and effective. Hakało and Wroński [27] made a comparative analysis of the results of treating patients $(n=17)$ with type II Hangman's fracture (Effendi classification). Nine patients underwent anterior transoral spondylodesis of $\mathrm{C}_{2}-\mathrm{C}_{3}$, eight patients were performed $\mathrm{C}_{2}$ transpedicular spondylosynthesis. The authors came to the conclusion that Judet's technique is a safer, economically affordable, and effective method of treatment. 
Liu et al. [28] published the work in which they have analyzed the results of treatment of 25 patients with Levine-Edwards types II, Ila traumatic $\mathrm{C}_{3}$ spondylolisthesis. Transpedicular fixation was done with modified screws. This modification is a Herbert'sbased double-threaded screw which can compress the fracture twice and from opposite sides. The authors obtained good results in all patients during 36 \pm 12 -month-follow-up.

In our work, the operation according to Judet's approach was performed in 19 patients with LevineEdwards type II Hangman's fracture, and good clinical and functional results were also obtained: postoperative VAS and NDI indices differed statistically significantly from those before the operation. We did not use this operation in types Ila, III fractures as we think that in case of the marked angulation there is an injury to $\mathrm{C}_{2}-$ $\mathrm{C}_{3}$ intervertebral disc and posterior longitudinal ligament, and therefore these fractures are unstable. In this case, $\mathrm{C}_{2}-\mathrm{C}_{3}$ fixation will be more justified.

Undoubtedly, the Judet operation is a technically difficult task due to large individual variations of $\mathrm{C}_{2}$ pedicle size and the course of the spinal artery. A screw runs through the vertebral pedicle which is medially limited by the spinal canal and spinal cord and laterally by the spinal artery. The screw diameter is $3.5 \mathrm{~mm}$, while the width of the pedicle through which it must pass is, on average, $5-7 \mathrm{~mm}$, at the same time, the screw passage is further complicated by the fracture with fragment disposition which changes the 3D anatomy of the posterior axis ring. According to the literature, the incidence of damage to the vital structures in transpedicular screw installation in the cervical spine varies from 11 to $66 \%$ [29]. Therefore, to install a screw successfully, careful preoperative preparation and three-dimensional presentation of vertebral pedicle morphology are necessary [30]. In our work, no significant malposition of the screws (>2 $\mathrm{mm}$ ) after the operative treatment has been noted.

\section{Conclusion}

Transpedicular osteosynthesis with compression screws is a sparing and safe operation with a short duration $(70.8 \pm 24.5 \mathrm{~min})$ and low level of blood loss $(92.9 \pm 41.8 \mathrm{ml})$. The operation is difficult and must be performed with great caution to prevent possible severe complications. Thorough preoperative planning and knowledge of the anatomic landmarks will allow the effective performance of the operation under the $\mathrm{C}$-arm X-ray control without navigation systems.

Acknowledgement. We thank K.K. Takhmazyan, S.B. Malakhov, V.K. Shapovalov, I.E. Gritsayev, M.I. Tomina, A.V. Kuzmenko, A.A. Afaunov for their essential contribution to the writing of this article.

Study funding. The work was not supported by any financial source.
Conflicts of interest. The authors have no conflicts of interest to declare.

\section{References}

1. Anderson L.D., D'Alonzo R.T. Fractures of the odontoid process of the axis. J Bone Joint Surg Am 1974; 56(8): 16631674.

2. Robinson A.L., Olerud C., Robinson Y. Epidemiology of $C_{2}$ fractures in the $21^{\text {st }}$ century: a National Registry cohort study of 6,370 patients from 1997 to 2014. Adv Orthop 2017; 2017: 6516893, https://doi.org/10.1155/2017/6516893.

3. Ryan M.D., Taylor T.K.F. Odontoid fractures in the elderly. J Spinal Disord 1993; 6(5): 397-401, https://doi. org/10.1097/00002517-199306050-00005.

4. Vieweg U., Meyer B., Schramm J. Differential treatment in acute upper cervical spine injuries: a critical review of a single-institution series. Surg Neurol 2000; 54(3): 203-211, https://doi.org/10.1016/s0090-3019(00)00301-3.

5. Benzel E.C., Hart B.L., Ball P.A., Baldwin N.G., Orrison W.W., Espinosa M. Fractures of the C-2 vertebral body. J Neurosurg 1994; 81(2): 206-212, https://doi.org/10.3171/ jns.1994.81.2.0206.

6. Hadley M.N., Dickman C.A., Browner C.M., Sonntag V.K. Acute axis fractures: a review of 229 cases. J Neurosurg 1989; 71(5 Pt 1): 642-647, https://doi.org/10. 3e171/jns.1989.71.5.0642.

7. Schneider R.C., Livingston K.E., Cave A.J., Hamilton G. "Hangman's fracture" of the cervical spine. J Neurosurg 1965; 22: 141-154, https://doi.org/10.3171/jns.1965.22.2.0141.

8. Li X.F., Dai L.Y., Lu H., Chen X.D. A systematic review of the management of hangman's fractures. Eur Spine $J$ 2006; 15(3): 257-269, https://doi.org/10.1007/s00586-005-0918-2.

9. Coric D., Wilson J.A., Kelly D.L. Jr. Treatment of traumatic spondylolisthesis of the axis with nonrigid immobilization: a review of 64 cases. J Neurosurg 1996; 85(4): 550-554, https://doi.org/10.3171/jns.1996.85.4.0550.

10. Vaccaro A.R., Madigan L., Bauerle W.B., Blescia A., Cotler J.M. Early halo immobilization of displaced traumatic spondylolisthesis of the axis. Spine (Phila Pa 1976) 2002; 27(20): 2229-2233, https://doi.org/10.1097/00007632200210150-00009.

11. Ferro F.P., Borgo G.D., Letaif O.B., Cristante A.F., Marcon R.M., Lutaka A.S. Traumatic spondylolisthesis of the axis: epidemiology, management and outcome. Acta Ortop Bras 2012; 20(2): 84-87, https://doi.org/10.1590/s141378522012000200005.

12. Al-Mahfoudh R., Beagrie C., Woolley E., Zakaria R., Radon M., Clark S., Pillay R., Wilby M. Management of typical and atypical hangman's fractures. Global Spine J 2016; 6(3): 248-256, https://doi.org/10.1055/s-0035-1563404.

13. Prost S., Barrey C., Blondel B., Fuentes S., Barresi L., Nicot B., Challier V., Lleu M., Godard J., Kouyoumdjian P., Lonjon N., Marinho P., Freitas E., Schuller S., Allia J., Berthiller J., Charles Y.P.; French Society for Spine Surgery (SFCR). Hangman's fracture: management strategy and healing rate in a prospective multi-centre observational study of 34 patients. Orthop Traumatol Surg Res 2019; 105(4): 703707, https://doi.org/10.1016/j.otsr.2019.03.009.

14. Bazhanov S.P., Gulyaev D.A., Norkin I.A., Ostrovskiy V.V., Primak N.A. Method for posterior spinal fusion in traumatic injuries of upper cervical spine. Patent RU 2511485. 2014. 
15. Leconte P. Fracture et luxation des deux premieres vertèbres cervicales. In: Luxation Congénitale de la Hanche. Fractures du Cou-de-pied Rachis Cervical. Actualités de Chirurgie Orthopédique de l'Hôpital Raymond-Poincaré, Vol 3. Judet R. (editor). Paris: Masson et Cie; 1964; p. 147-166.

16. Judet R., Roy-Camille R., Saillant G. Actualités de chirurgie orthopédique de l'Hospital Raymond-Poincaré. In: Judet R. (editor). Fractures du rachis cervical. Paris: Masson; 1970; p. 174-195.

17. Levine A.M., Edwards C.C. The management of traumatic spondylolisthesis of the axis. $J$ Bone Joint Surg Am 1985; 67(2): 217-226.

18. Effendi B., Roy D., Cornish B., Dussault R.G., Laurin C.A. Fractures of the ring of the axis. A classification based on the analysis of 131 cases. J Bone Joint Surg Br 1981; 63-B(3): 319327, https://doi.org/10.1302/0301-620x.63b3.7263741.

19. Ma W., Xu R., Liu J., Sun S., Zhao L., Hu Y., Jiang W., Liu G., Gu Y. Posterior short-segment fixation and fusion in unstable hangman's fractures. Spine (Phila Pa 1976) 2011; 36(7): 529-533, https://doi.org/10.1097/ brs.0b013e3181d60067.

20. Xie N., Khoo L.T., Yuan W., Ye X.J., Chen D.Y., Xiao J.R., $\mathrm{Ni}$ B. Combined anterior $\mathrm{C}_{2}-\mathrm{C}_{3}$ fusion and $\mathrm{C}_{2}$ pedicle screw fixation for the treatment of unstable hangman's fracture: a contrast to anterior approach only. Spine (Phila Pa 1976) 2010; 35(6): 613-619, https://doi.org/10.1097/brs.0b013e3181ba3368.

21. Ying Z., Wen Y., Xinwei W., Yong T., Hongyu L., Zhu H., Qinggang Z., Weihong Z., Yonggeng C. Anterior cervical discectomy and fusion for unstable traumatic spondylolisthesis of the axis. Spine (Phila Pa 1976) 2008; 33(3): 255-258, https://doi.org/10.1097/brs.0b013e31816233d0.

22. Gubin A.V., Burtsev A.V., Ryabikh S.O. Posterior fixation of hangman's fractures. Hirurgia pozvonocnika 2014; 4: 15-19, https://doi.org/10.14531/ss2014.4.15-19.
23. EIMiligui Y., Koptan W., Emran I. Transpedicular screw fixation for type II hangman's fracture: a motion preserving procedure. Eur Spine J 2010; 19(8): 1299-1305, https://doi. org/10.1007/s00586-010-1401-2.

24. Borne G.M., Bedou G.L., Pinaudeau M. Treatment of pedicular fractures of the axis. A clinical study and screw fixation technique. J Neurosurg 1984; 60(1): 88-93, https://doi. org/10.3171/jns.1984.60.1.0088.

25. Verheggen R., Jansen J. Hangman's fracture: arguments in favor of surgical therapy for type II and III according to Edwards and Levine. Surg Neurol 1998; 49(3): 253-262, https://doi.org/10.1016/s0090-3019(97)00300-5.

26. Boullosa J.L., Colli B.O., Carlotti C.G. Jr., Tanaka K., dos Santos M.B. Surgical management of axis' traumatic spondylolisthesis (hangman's fracture). Arq Neuropsiquiatr 2004; 62(3B): 821-826, https://doi.org/10.1590/s0004$282 \times 2004000500015$.

27. Hakało J., Wroński J. Operative treatment of hangman's fractures of $\mathrm{C}_{2}$. Posterior direct pars screw repair or anterior plate-cage stabilization? Neurol Neurochir Pol 2008; 42(1): 28-36.

28. Liu Y., Zhu Y., Li X., Chen J., Yang S., Yang H., Jiang W. A new transpedicular lag screw fixation for treatment of unstable Hangman's fracture: a minimum 2-year followup study. J Orthop Surg Res 2020; 15(1): 372, https://doi. org/10.1186/s13018-020-01911-3.

29. Ludwig S.C., Kowalski J.M., Edwards C.C. $2^{\text {nd }}$, Heller J.G. Cervical pedicle screws: comparative accuracy of two insertion techniques. Spine (Phila Pa 1976) 2000; 25(20): 2675-2681, https://doi.org/10.1097/00007632-200010150-00022.

30. Abumi K., Kaneda K. Pedicle screw fixation for nontraumatic lesions of the cervical spine. Spine (Phila Pa 1976) 1997; 22(16): 1853-1863, https://doi.org/10.1097/00007632199708150-00010. 